\title{
Turystyka jako główna forma rozwoju społeczno-gospodarczego Huculszczyzny w okresie II Rzeczpospolitej Polskiej
}

\author{
Stanisław Piekarski ${ }^{1 *}$, Jacek Oleksiejuk ${ }^{2}$ \\ 1 AWF Warszawa \\ 2 Społeczna Akademia Nauk w Warszawie \\ * stanislaw.piekarski@awf.edu.pl
}

\begin{abstract}
Streszczenie
Jednym z bardziej fascynujących regionów kulturowo-klimatycznych Drugiej Rzeczypospolitej Polskiej była Huculszczyzna, położona w województwie stanisławowskim. Początkowo region ten pozostawał poza kręgiem zainteresowań organizatorów działalności turystycznej. Dopiero na początku lat trzydziestych XX wieku uznano, że Huculszczyzna powinna stać się ważnym elementem polskiej polityki turystyczno-sportowej. Do realizacji tego zadania skierowano przede wszystkim ówczesne Ministerstwo Spraw Wojskowych. Ważna rola przypadła też utworzonemu w 1932 roku Towarzystwu Przyjaciół Huculszczyzny. W latach 1933-1935, w okresach letnich, organizowano ogólnopolskie Święta Huculszczyzny. Ich zimowym odpowiednikiem były Zimowe Marsze Huculskim Szlakiem II Brygady Legionów Polskich. Imprezom turystyczno-sportowym, w dużej mierze o charakterze polityczno-propagandowym, towarzyszyła walka o poprawę infrastruktury turystycznej. Głównym tego przejawem było zbudowanie w latach 1935-1938 okazałego Muzeum Huculskiego w Żabiem. W efekcie, pod koniec międzywojnia, Huculszczyzna stała się pod względem turystycznym regionem konkurującym o pierwszeństwo z Tatrami i Zakopanem.
\end{abstract}

\section{Słowa kluczowe}

Huculszczyzna, turystyka, sport, rekreacja, marsze zimowe, Legiony Polskie, muzeum, Towarzystwo Przyjaciół Huculszczyzny

\section{Wprowadzenie}

Z chwilą odzyskania w 1918 roku przez nasz kraj niepodległości, w jego granicach znalazło się około $20.000 \mathrm{~km}^{2}$ "polskich gór" (19, s. 4). Jednak w pierwszym dziesięcioleciu Drugiej Rzeczpospolitej w centrum uwagi pozostawało przede wszystkim Zakopane i tereny okolicznego Podhala. Między innymi w listopadzie 1919 roku Ministerstwo Robót Publicznych (MRP) w gestii którego mieściła się wówczas turystyka - przeprowadziło ankietę rządową w sprawie rozwoju turystyki w zimowej stolicy Polski. Podobna ankieta w sprawie rozwoju turystyki tatrzańskiej została zrealizowana w marcu 1929 roku (Orłowicz 1935: 3). W tym czasie prawie w ogóle nie dostrzegano problematyki rozwoju turystyki w Karpatach Wschodnich, położonych głównie na terenie województwa stanisławowskiego. Dopiero w dniach 29-30 maja 1931 roku, w Stanisławowie, wspomniane 
wyżej MRP po raz pierwszy zorganizowało ogólnopolską ankietę w sprawie rozwoju turystyki w tej części gór polskich. Sformułowano kilkadziesiąt postulatów, z których główne dotyczyły rozbudowy infrastruktury turystycznej i podjęcia wzmożonej promocji turystyczno - kulturowej wszystkich gór polskich (Orłowicz 1932: 14 - 91). 29 czerwca 1932 roku, w Warszawie, konferencję w sprawie zaktywizowania działalności turystycznej w „Polskich Karpatach” zorganizował Państwowy Urząd Wychowania Fizycznego i Przysposobienia Wojskowego (PUWF i PW). W kolejnych latach „doroczne”, ogólnopolskie konferencje w tej sprawie organizowało Ministerstwo Komunikacji (MK) (Orłowicz 1935: 3 - 4). W takich okolicznościach, na początku lat trzydziestych XX wieku, „Góry Polskie” stały się dla oficjalnych władz i milionów Polaków krainą nie tylko wielkich szans i nadziei, ale też elementem rozwijania rodzimego patriotyzmu.

W pierwszej kolejności starano się eksponować dotychczas zapomnianą „Polską Huculszczyznę", zajmującą teren około $2.500 \mathrm{~km}^{2}$, posadowiony we wschodniej części Karpat, z pięknym pasmem Czarnohory i malowniczymi dolinami Prutu i Czeremoszu. Na tym terenie w roku 1931 roku mieszkało około 450.0oo osób. Celem niniejszego artykułu jest zaprezentowanie problematyki dotyczącej promocji turystyczno - kulturowej Huculszczyzny w okresie Drugiej Rzeczpospolitej Polskiej oraz podejmowanych w tym czasie działań na rzecz ożywienia gospodarczego tego regionu. Do napisania artykułu między innymi wykorzystano dokumenty i materiały znajdujące się w Centralnym Archiwum Wojskowym (CAW) i Archiwum Akt Nowych (AAN) oraz informacje zamieszczane $\mathrm{w}$ gazetach i periodykach okresu międzywojennego.

Huculszczyzna pozostająca w granicach Polski od XIV wieku, a od XIX wieku stała się uosobieniem rodzimego romantyzmu. Prawie każde polskie opracowanie ukazujące się na początku lat trzydziestych XX wieku, a dotyczące Huculszczyzny, zaczynało się od stwierdzenia, że jest to kraina dotąd wcale nie znana (Zieleniewski 1934: 3). Sentymentalny stosunek do Huculszczyzny czytelny jest w wielu środowiskach współczesnych mieszkańców „kraju nad Wisłą”. Dla jednych jest ona „pięknem ziemi utraconej” (Hordt 1998: 68), dla innych „rajem dawnej polskiej ziemi”, czy też „światem gorącego uczucia” (Choroszy 1991: 17 i 153). Zdaniem Jerzego Kolankowskiego: „Huculszczyźnie położonej na skraju Rzeczpospolitej, wciśniętej między bruzdy granic, a jednocześnie zadomowionej w polskiej tradycji kulturowej przysługiwał status krainy osobliwej i egzotycznej" (Kolankowski 1989: 102). Gwara huculska pochodzi z grupy karpackich języków ruskich. Huculi zajmowali się głównie hodowlą bydła, pasterstwem, flisactwem i przemysłem leśnym. Udało im się wytworzyć tradycje kulturowe i folklor z charakterystycznym strojem ludowym, pieśniami (kołomyjki), legendami i rzemiosłem artystycznym. Swego rodzaju symbolami tej ziemi były niewielkie, "górskie" konie huculskie (około 140 cm wysokości w kłębie) i instrumenty dęte, zwane trombitami. Te ostatnie miały kształt długich, na końcu nieco zagiętych rur, których długość dochodziła do 4 metrów. Instrument wykonywany był przeważnie $\mathrm{z}$ drewna świerkowego i używano go do uświetniania ważnych uroczystości rodzinnych, kościelnych i państwowych.

Wielki zachwyt wzbudzały też niewielkie drewniane chaty, zwane grażdami, wyglądające jak obronne zameczki, z dachami czterookapowymi, pięknie złamanymi i ozdobionymi wyczółkami. Jak zauważono w jednym z opracowań, wydanych w 1934 roku: „Skłonność do zdobienia pojawia się u Hucułów niemal na każdym kroku. Nie tylko zdobią drzwi chaty, ale nawet strzemiona siodła, jarzma i inne przedmioty codziennego użytku. Wszystko jest rzeźbione w piękne, geometryczne wzory" (29, s. 13-14). Huculską osobliwością były też „posiżyny” i zwyczaj „pobratymstwa”. Te pierwsze wiązały się z tradycją „rozśmieszania” najbliższych osoby zmarłej, aby „uciszyć ich żałość po wielkiej stracie” (Hordt 1998: 183). Pobratymstwo tymczasem - to 
ceremonia organizowana w cerkwi, podczas której dwie osoby nie związane ze sobą rodzinnie, zawierały „porozumienie”, na mocy którego stawały się przybranym „rodzeństwem". Warto też zastanowić się nad etymologią słowa „Hucuł”. W tej sprawie w cytowanym powyżej wydawnictwie napisano: „Nazwa Hucuł jest stosunkowo nowa. Za czasów Polski przedrozbiorowej jej nie znano[...] Sami Huculi nazywali swój kraj Wierchowiną, siebie Wierchowińcami. Nazwa ta pochodzi zdaje się od sąsiednich Rumunów jeszcze z czasów, kiedy zbójnicy huculscy zwani opryszkami dawali się okolicznym krajom we znaki. „Hocuł” oznacza bowiem po rumuńsku zbójnika, względnie bojownika" (29, s. 14). W tym miejscu warto nadmienić, że zainteresowanie specyficzną kulturą huculską wykazywali nie tylko Polacy, ale także inne nacje europejskie, w tym przede wszystkim Szwajcarzy (17).

\section{Towarzystwo Przyjaciół Huculszczyzny (1932-1939)}

Ważnym wydarzeniem w historii Karpat Wschodnich było utworzenie pod koniec 1932 roku Towarzystwa Przyjaciół Huculszczyzny (TPH). Organizacja została oficjalnie wpisana do Rejestru Stowarzyszeń i Związków Komisariatu Rządu w Warszawie dopiero 12 grudnia 1933 roku. Jej prezesem został gen. dyw. Tadeusz Kasprzycki, ówczesny wiceminister spraw wojkkowych (od 1935 roku - minister tego resortu). Celem organizacji było:

- $\quad$ współdziałanie w planowym rozwoju Huculszczyzny pod względem ogólno-kulturalnym i ekonomicznym;

- ochrona specjalnych wartości Huculszczyzny, składających się na jej regionalną odrębność, stanowiącą cenny składnik bogactw naturalnych i duchowych Rzeczypospolitej Polskiej;

- praca nad racjonalnym wykorzystaniem klimatycznych wartości Huculszczyzny dla celów higieny społecznej Państwa;

- opieka i praca nad planowym rozwojem na Huculszczyźnie ru- chu turystycznego, letniskowego i uzdrowiskowego.

Swoje cele towarzystwo miało realizować poprzez:

- $\quad$ inicjatywy zmierzające do zespolenia w swych ramach i uzgadniania wysiłków wszystkich instytucji i osób mających na celu wszechstronne podniesienie Huculszczyzny;

- prowadzenie i popieranie niezbędnych dla realizacji zadań T.P.H. prac naukowych oraz badań na miejscu i wydawnictw w tym zakresie;

- przedkładanie władzom ustawodawczym i administracyjnym petycji i memoriałów opartych na obiektywnych badaniach w terenie;

- współdziałanie w ochronie przyrody, krajobrazu i folkloru huculskiego, a szczególnie sztuki ludowej;

- opiekowanie się, popieranie i tworzenie organizacji i instytucji gospodarczych, oświatowych, sportowych, humanitarnych i społecznych, które bądź wyłącznie, bądź tylko częściowo pracowały na Huculszczyźnie;

- nabywanie i zbywanie majątku ruchomego i nieruchomego, subwencji, zapisów, darowizn i ofiar;

- uprawianie intensywnej propagandy dotyczącej problematyki Huculszczyzny, poprzez odpowiednie wydawnictwa, udzielanie informacji, urządzanie odczytów, przedstawień, wycieczek, publikacje artykułów prasowych, itp.;

- pracę uświadamiającą wśród ludności huculskiej, w szczególności ruchu świetlicowego, działalności humanitarnej do uzdrowienia miejscowych stosunków gospodarczych i akcji wśród Hucułów, urabiającej świadomość ich o swoistości i wartości etnicznej oraz zachęcającej ich do noszenia dawnych strojów, języka, obyczajów, zwyczajów, budownictwa, sztuki, itp. (34, s. 4-6).

Utworzone na początku lat trzydziestych XX wieku TPH od początku cieszyło się wielką atencją oficjalnych czynników 
rządowych. Z organizacją tą wiązano bowiem ogromne nadzieje, również w sferze ostatecznej polonizacji tego regionu. Nie przypadkowo jej prezesem został wiceszef resortu obrony narodowej... Należało więc oczekiwać dynamicznego, „żołnierskiego” zainteresowania problematyką, tego niewielkiego skrawka ziemi nie tylko przez wojsko, ale głównie przez ówczesne masowe środki przekazu. Stwarzało to wielkie możliwości turystyczno - kulturowej promocji Huculszczyzny, nie tylko w wymiarze krajowym, ale również europejskim.

\section{3. Święta Huculszczyzny (1933-1935)}

Jedną z pierwszych inicjatyw TPH była propozycja zorganizowania w dniach $15-18$ czerwca 1933 roku ogólnopolskiej imprezy pod nazwą „Święta Huculszczyzny”. Jej celem miało być „danie możności poznania najszerszym warstwom ludności polskiej Huculszczyzny i ożywienie życia turystyczno - gospodarczego na tym terenie (38, s. 6). Pomysł zorganizowania „Święta Huculszczyzny" z wielką aprobatą został przyjęty w tzw. oficjalnych kręgach rządowych (7). Między innymi Ministerstwo Komunikacji,- - w ramach którego mieściła się wówczas problematyka działalności turystycznej- zobowiązało się w czasie trwania imprezy skierować do Stanisławowa dodatkowo kilkanaście pociągów popularnych i aż o 70\% obniżyć ceny biletów kolejowych na „przejazdy huculskie”.

Już w lutym 1933 roku powołano Komitet Obywatelski imprezy, na czele z Zygmuntem Jagodzińskim - ówczesnym wojewodą stanisławowskim. Ukonstytuowano też Komitet Wykonawczy, składający się z sekcji: propagandowej, organizacyjnej, komunikacyjnej, imprezowej i aprowizacyjno - mieszkaniowej. Zgodnie z przyjętą koncepcją goście „Święta Huculszczyzny” mieli koleją przyjeżdżać do Stanisławowa, aby stąd "transportem kołowym” dotrzeć do następujących miejscowości: Kuty, Kołomyja, Jaremcze, Worochta, Jamna, Dora, Mikuliczyn i Nadwórna. Ustalono też, że w dolinie Prutu kursować będzie „tramwaj górski", a ceny jednodniowego zakwaterowania i wyżywienia w pensjonatach nie mogą przekraczać 5 zł (31, s. 8). Ogółem do stolicy Huculszczyzny miało przybyć około 20.000 osób. Miały one mieć do dyspozycji 5 tras turystycznych. Generalnie większość założeń zostało zrealizowanych.

Trasa numer 1 wiodła z Kut do Kosowa, ze stacją docelową w Kołomyi. Turyści mieli okazję między innymi zwiedzić kilka wystaw regionalnych, odbyć kilkanaście wycieczek górskich (w tym również do Wyżnicy położonej na terytorium Rumunii), bliżej poznać Dolinę Pistynki, obejrzeć pokazy łowienia pstrągów oraz prezentacje regionalnych tradycji i zwyczajów.

Trasa numer 2 prowadziła z Żabiego do Kosowa. W programie było między innymi kilkanaście wycieczek przygotowanych przez komitety lokalne, zwiedzanie miejscowych salin i wytwórni kilimów, występy regionalnych zespołów muzycznych, pokazy wyrobów rzemieślniczych i kilka zabaw ludowych (12).

Trasa numer 3 przewidywała zwiedzanie Kołomyi, Kosmacza, Peczeniżyna i Słobody. W programie były wycieczki piesze i konikami huculskimi, występy teatralne, wystawy plastyczne, pokazy produkcji kilimów i wyrobów sztuki ludowej.

Trasa numer 4 obejmowała zwiedzanie miejscowości położonych od Nadwornej do Worochty. Oprócz tradycyjnych pieszych wycieczek górskich goście mieli okazję obejrzeć festiwal tańców huculskich i uczestniczyć w kilku festynach ludowych.

Trasa numer 5 została przygotowana „dla wybitnych turystów, którzy chcieli dotrzeć na najwyższe szczyty Gorgan” (38, s. 6). Oprócz „specjalistycznych” wycieczek górskich turyści mogli też zwiedzać Nadwórną, Pasieczną, Zieloną i Rafajłową. Przewodnikami przy realizacji trudnych wycieczek górskich byli reprezentanci Polskiego Towarzystwa Tatrzańskiego (PTH). Wycieczki o mniejszej skali trudności prowadzili przewodnicy skierowani przez wspomniane wyżej komitety lokalne (38, s. 6). Szczegółowy program imprezy został 
zawarty w okolicznościowej broszurze, wydanej w nakładzie 5 tysięcy egzemplarzy (37). Większość założeń organizacyjno-programowych zostało zrealizowanych.

Sporo działań logistyczno-zabezpieczających zlecono żołnierzom Wojska Polskiego. Dzięki żołnierzom z kompani reflektorów z Nowego Dworu możliwe były nocne efekty świetlne, podziwiane przez wszystkie dni trwania imprezy. Za łączność w tym czasie odpowiadał baon telegraficzny z Krakowa. Transportem ludzi i sprzętu zajmowali się szoferzy 5 baonu czołgów. Żołnierze stanowili też obsługę kilkunastu kuchni polowych. Na uwagę zasługuje też fakt, że w ramach święta bezustannie koncertowało też pięć orkiestr wojskowych (42, s. 486).

Generalnie pierwszą edycję „Święta Huculszczyzny" uznano za przedsięwzięcie bardzo udane. Jedynym, poważnym kłopotem był chaos transportowy związany $\mathrm{z}$ niepunktualnym przybywaniem pociągów i problemy związane z przewożeniem ludzi ze Stanisławowa do miejscowości „docelowych" (13). W takich okolicznościach podjęto decyzję, że w roku 1934 uroczystości "Święta Huculszczyzny” odbywać się będą "równolegle” w dwóch miejscowościach: Żabiem i Worochcie, a jego uczestnicy do miejsc wydarzeń będą docierać we własnym zakresie. Aby im zrekompensować nieco trudy związane z podróżowaniem, zniżki kolejowe przyznano im w wysokości aż 75\% (36, s. 4).

Druga edycja „Święta Huculszczyzny” odbyła się zgodnie $\mathrm{z}$ planem $\mathrm{w}$ dniach $7-8$ lipca 1934 roku. Pierwszego dnia odprawiono uroczystą msza świętą na błoniach Worochty, a następnie spora grupa turystów uczestniczyła w poświęceniu i uroczystym otwarciu nowego schroniska P.T.T.K. na Połoninie Baraniej, pod Chomiakiem. W jednym czasie mogło w nim mieszkać 50 osób. Z Worochty goście wyruszali na wycieczki piesze i autokarowe zarówno w góry jak i do pobliskich miejscowości. Największym zainteresowaniem cieszyła się wycieczka na Szczyt Worochteński. W godzinach wieczornych na dużej scenie prezentowały się teatry huculskie. Między innymi wystąpił znany teatr huculski z Żabiego, z prezentacją „Karpackich Górali” Józefa Korzeniowskiego. Przedstawienie odbyło się z wykorzystaniem „języka huculskiego". Następnego dnia - kolejna grupa turystów mogła zwiedzić nowo otwarte schronisko pod Chomiakiem oraz odbyć wycieczkę na Mikulinę. Ważną atrakcję stanowił przemarsz ulicami miasta barwnego orszaku weselnego oraz wyścigi na konikach huculskich. Sporym zainteresowaniem gości cieszył się też zlot gwiaździsty starych samochodów i motocykli, zakończony szczegółowym pokazem nagrodzonych marek i modeli. Warto też odnotować, że w kiosku na dworcu kolejowym w Worochcie przez wszystkie dni trwania imprezy funkcjonowało biuro informacyjno-wycieczkowe i punkt wymiany walut (2, s. 22).

Równolegle podobne przedsięwzięcia odbywały się w pobliskim Żabiem. Tu również „Święto Huculszczyzny” rozpoczęto uroczystym nabożeństwem odprawionym w miejscowej cerkwi. Po nim nastąpiło otwarcie wystawy przemysłu huculskiego. Dużo też było koncertów muzycznych, w tym między innymi popisy gry na fujarkach i na trombitach. Tradycyjnie w programie znalazło się też kilkanaście wycieczek i konkurs strojów huculskich. Na koniec odbyły się zawody w konkurencji broni małokalibrowej o odznakę strzelecką i bieg sztafetowy o nagrodę ministra spraw wojskowych (2, S. 22).

Swego rodzaju finałem drugiej edycji "Święta Huculszczyzny” było nawiązanie do... „Święta Morza”. Oto bowiem 8 lipca w godzinach popołudniowych na stację w Worochcie wjechał model okrętu „Wicher”, zainstalowany - z inicjatywy Ligi Morskiej na lokomotywie (45, s. 3). Z okazji drugiej edycji „Święta Huculszczyzny” ukazała się okolicznościowa „Jednodniówka”, z prezentacją piękna i osiągnięć tego wyjątkowego regionu (29).

"Święto Huculszczyzny” zorganizowane w 1934 roku uznano za najważniejsze wydarzenie Karpat Wschodnich, być może i dlatego, że uczestniczyła w nim liczna grupa ministrów z Warszawy (29). W jednym 
z dokumentów „rządowych” sporządzonych jesienią 1934 roku napisano: „Do niedawna Huculszczyzna była dla większości społeczeństwa jakąś daleką, egzotyczną i trudno dostępną krainą, aż dopiero w ostatnim czasie została jakby na nowo odkryta i cieszy się już dużym zainteresowaniem turystów” (17).

Kolejną edycję "Święta Huculszczyzny” zaplanowano w terminie 12 - 14 lipca 1935 roku. Koncepcja imprezy miała być niemal identyczna jak w roku poprzednim. Oprócz Worochty i Żabiego, do organizacji imprezy miały też być włączone Jaremcze (40, S. 2).

Ostatecznie impreza została zrealizowana w bardzo ograniczonym wymiarze, a to dlatego, że w roku 1935 priorytetem było „Święto Gór”, realizowane w dniach 3-11 sierpnia w Zakopanem. Jego głównym organizatorem był gen. Tadeusz Kasprzycki, pełniący w tym czasie również funkcję prezesa Związku Ziem Górskich. Słusznie zatem uznano, że nie ma sensu prawie w jednym czasie organizować dwóch podobnych imprez. W takich okolicznościach problematyka huculska po raz pierwszy - z wielkim powodzeniem - została zaprezentowana właśnie podczas „Święta Gór”. Pokazano ją również podczas kolejnego „Święta Gór”, zorganizowanego w dniach $15-17$ sierpnia 1936 roku w Sanoku. W roku 1937 po raz pierwszy zorganizowano w Wiśle „Tydzień Gór Polskich”. Kasprzyckiemu przypadł zaszczyt uroczystego otwarcia tej imprezy. Bardzo znamiennie zabrzmiały przy tej okazji słowa generała, że „wojsko stworzy na Huculszczyźnie mur piersi żołnierskich, za którym spokojnie żyć będzie ojczyzna" (26, s. 1). Za wydarzenie artystyczne uznano inscenizację „Wesela Huculskiego”, które na tych terenach trwało od trzech do sześciu dni. W rolę aktorów wcieliła się grupa $\mathrm{Hu}-$ cułów z Mikuliczyna, jednej z najstarszych osad nad Prutem (43, s. 7). Podczas trwania „Tygodnia Gór Polskich” zaprezentowano również zamierzenia inwestycyjne. Na czoło wysuwała się budowa wielkiej szosy wzdłuż Karpat, mającej połączyć Huculszczyznę z Beskidem Śląskim. Pierwszym etapem tego zamierzenia była budowa drogi z Żabiego do Burkutu. Do listopada 1937 roku zbudowano $18 \mathrm{~km}$ tej 36 kilometrowej trasy. Po oddaniu do użytku pierwszego odcinka drogi w jednej z gazet napisano: „Budowa tej trasy utworzy najpiękniejszą drogę górską w Polsce. Otworzy to nowe perspektywy rozwoju dla Burkutu, jednej z najbardziej interesującej miejscowości Huculszczyzny" (44, s. 6).

Kolejna edycja „Święta Gór” odbyła się w dniach 12-15 sierpnia 1938 roku w Nowym Targu. W niej również uczestniczyła ponad stuosobowa reprezentacja Huculszczyzny, występując głównie na placach miejskich i scenach estradowych. Piątą edycję „Święta Gór” miał stanowić „Międzynarodowy Tydzień Gór", planowany w terminie 7-12 września 1939 roku w Zakopanem. Z oczywistych powodów impreza nie mogła być zrealizowana.

„Święto Huculszczyzny” z wielkim rozmachem organizowane w latach 1933-1934 było więc pierwszą tego typu ogólnopolską imprezą "górską" w Polsce, gromadzącą tak liczne rzesze turystów i sympatyków krajoznawstwa. Nigdy wcześniej centralne władze kraju nie były w takim wymiarze angażowane do promocji turystyki górskiej w najlepszym tego słowa znaczeniu. Można nawet przyjąć, że dzięki „Święcie Huculszczyzny”, powstał ogólnopolski system popularyzacji turystyki górskiej, który przetrwał do końca okresu międzywojennego.

\section{Zimowe Marsze Huculskim Szlakiem II Brygady Legionów Polskich (1934-1939)}

Kolejną formą aktywizacji społeczno-gospodarczej Huculszczyzny były ogólnopolskie zimowe marsze narciarskie Huculskim Szlakiem II Brygady Legionów Polskich. Ten słynny związek taktyczny Józefa Piłsudskiego oficjalnie powstał w maju 1915 roku. W jego skład weszły utworzone we wrześniu 1914 roku 2 i 3 Pułki Piechoty Legionów. Już miesiąc później wspomniany wyżej 3 Pułk Piechoty został skierowany na front, przebiegający w tym czasie przez Huculszczyznę. W ciągu kilku dni polscy żołnierze zbudowali górską przeprawę przez Przełęcz 
Rogodze Wielkie (nazywaną też Pantyrską), w głównym paśmie Gorganów. Była nią siedmiokilometrowa droga wyłożona belkami, z ponad 20 mostkami. Połączyła ona miejscowość Konigsfeld z Rafajłową. W styczniu 1915 roku 3 Pułk Piechoty Legionów toczył tu krwawe walki z wojskami rosyjskimi. Poległych ponad 6o legionistów, pochowano na prowizorycznym cmentarzu, a w jego pobliżu ustawiono drewniany Krzyż Legionowy. W umieszczonej pod nim tablicy znalazł się napis: „Młodzieży polska patrz na ten krzyż! Legiony polskie dźwignęły go wzwyż. Przechodząc góry, lasy i wały Do Ciebie Polsko i dla twej chwały". Zmagania polskich żołnierzy utrwalił też malarz legionowy Zygmunt Grabowski, w swoich obrazach noszących tytuły „Bitwa pod Rafajłową” i „Odparcie nocnego wypadu moskali na Rafajłową w nocy z 23/24, stycznia 1915 roku". Miejscowa ludność podczas wydarzeń frontowych z wielką życzliwością odnosiła się do Legionistów, nazywając ich „sokolikami”. Spora liczba Huculi bezpośrednio wspierała polskich żołnierzy, pełniąc w ich pododdziałach rolę przewodników górskich i zwiadowców (33, S. 19-25).

Z chwilą odzyskania niepodległości zbudowaną w 1914 trasę nazwano Drogą Legionów. W 1931 roku wspomniany wyżej krzyż drewniany ustawiony na Przełęczy Pantyrskiej zastąpiono krzyżem żelaznym, z kamienną tablicą u podnóża. Ślady toczonych tu walk były widoczne jeszcze wiele lat później. Jeden z mieszkańców tej ziemi po latach napisał: „Na całym obszarze Karpat Wschodnich spotykało się świadectwa po I wojnie światowej jak okopy, ziemianki, zasieki z drutu kolczastego, pojedyncze groby z krzyżem, małe cmentarze otoczone drutami, ale też kości ludzkie i czaszki, które były wygrzebywane przez wilki i niedźwiedzie z płytkich grobów" (Hordt 1998: 178).

Naturalnie Polaków interesowały formy upamiętniania ludzi i zdarzeń związanych z historią jednostek legionowych. Taki cel miała zgłoszona przez wojsko w grudniu 1933 roku inicjatywa organizowania na tych terenach Zimowych Marszów Huculskim
Szlakiem II Brygady Legionów Polskich (8). Imprezy realizowane były w latach 19341939, prawie zawsze w połowie lutego. Łącznie odbyło się więc sześć ich edycji. Organizatorami imprezy byli: Ministerstwo Spraw Wojskowych, Państwowy Urząd Wychowania Fizycznego i Przysposobienia Wojskowego, Polski Związek Narciarski i TPH. Funkcję bezpośredniego realizatora imprezy pełnił dowódca 11 Dywizji Piechoty gen. Kazimierz Łukoski, której sztab stacjonował w Stanisławowie. Marsz składał się z trzech etapów, odbywających się w ciągu trzech dni. Czwartego dnia miało miejsce podsumowanie imprezy i uroczyste wręczenie nagród. Zawody najczęściej zaczynały się w Rafajłowej i zawsze kończyły się w Worochcie. Przez cały czas ich trwania, organizowano też przedsięwzięcia towarzyszące takie jak: występy artystyczne, wystawy, zabawy ludowe czy konkursy sportowe.

Uczestnikami marszu były patrole narciarskie, składające się z dowódcy i trzech zawodników. Funkcje dowódców pełnili przeważnie oficerowie młodsi, podoficerowie, a niekiedy też podchorążowie. W latach 1934-1936 obowiązywały dwie klasy drużyn: „mundurowa” i „cywilna”. W skład pierwszej wchodziły reprezentacje wojska, Korpusu Ochrony Pogranicza, Policji Państwowej i Straży Granicznej. W klasie drugiej znajdowały się drużyny przysposobienia wojskowego, Związku Strzeleckiego, itp. organizacji. W latach 1937-1939 oprócz kategorii wyżej wymienionych, funkcjonowały też klasy: trzecia i czwarta. W trzeciej znalazły się patrole sportowe, a w czwartej - regionalne. Oprócz klasyfikacji generalnej, prowadzona też klasyfikacja w ramach poszczególnych kategorii. Każdy zawodnik będący członkiem patrolu zobowiązany był do niesienia plecaka, ważącego przynajmniej $5 \mathrm{~kg}$.

Podczas trwania drugiego etapu wszystkie patrole zobowiązane były do przygotowania wieńca uplecionego z gałązek drzewa iglastego i złożenia go pod Krzyżem Legionowym na Przełęczy Pantyrskiej. Stąd też w latach 1934-1935 każdy patrol pobierał grudki ziemi, aby złożyć je w dniu 
zakończenia marszu, pod Krzyżem Sobieskiego w Worochcie. Począwszy od roku 1936 patrole nie pobierały już do tulejki ziemi spod krzyża, tylko czyniła to w ich imieniu delegacja kół pułkowych II Brygady Legionów Polskich. Ziemię tę podczas zakończenia imprezy przekazywano zwycięskiej drużynie, która zobowiązana była zawieźć ją na Kopiec Piłsudskiego na Sowińcu, pod Krakowem.

Bardzo ważnym elementem marszu było strzelanie, organizowane 3-4 km przed metą trzeciego etapu. W trakcie dwóch pierwszych edycji do czterech tarcz strzelali wszyscy członkowie zespołu, mając łącznie do dyspozycji 20 naboi. Od roku 1936 ze strzelania „zwolnieni” byli dowódcy patroli. Pozostali trzej członkowie drużyny mieli do dyspozycji po 5 sztuk amunicji, które należało umieścić w trzech tarczach. Obowiązywała pozycja „dowolna”, a cele ustawione były w odległości $100 \mathrm{~m}$ od linii ognia. W roku 1939 zamiast tarcz, w odległości 130 m od strzelających, zamontowano kolorowe baloniki, o średnicy $30 \mathrm{~cm}$. Za każdy celny strzał zespołowi od uzyskanego czasu odejmowano ustaloną regulaminem „porcję" czasu (5-15 minut). Minutami karnymi natomiast karano strzały chybione. O ostatecznym wyniku marszu zespołu decydował więc łączny czas uzyskany na trzech etapach i wynik zespołowego strzelania.

Oprócz klasyfikacji drużynowej, prowadzono także klasyfikacje zawodników startujących indywidualnie (podział na kategorie wiekowe i grupę pań). Przy czym narciarze ci nie byli zobowiązani do dźwigania pięciokilogramowego plecaka i nie brali udziału w strzelaniu. Każdy uczestnik zawodów miał prawo do siedmiodniowego płatnego urlopu i bezpłatnego przejazdu kolejowego. Również osoby „towarzyszące” i zwykli widzowie przyjeżdżające na Huculszczyznę w okresie realizacji marszu mieli prawo ubiegania się o kilkudniowy, w pełni płatny urlop oraz do $70 \%$ ulgi na zakup biletów podróży.

Sporym ułatwieniem dla podróżnych udających się na zawody, była zwiększona liczba tzw. pociągów popularnych, „organizowanych” przez MK. Przyjeżdżających na zawody zawodników kwaterowano przeważnie w schroniskach PTTK, bez specjalnych wygód (słoma lub siano + prześcieradło i koc). Gości zasiadający na widowni mieszkali głównie w pensjonatach i kwaterach prywatnych. Sporym ułatwieniem dla jednych i drugich były punkty informacyjno - turystyczne, organizowane przeważnie na dworcach kolejowych. Ważną rolę pełniły też komitety lokalne powoływane na czas trwania imprezy w 4-6 miejscowościach huculskich. Wyżywienie uczestników marszów zapewniały pułki 11 Dywizji Piechoty, w dużej mierze wykorzystując kuchnie polowe.

Przeciętna długość całego marszu wynosiła około $77 \mathrm{~km}$. Przeważnie "maszerowano” trasą: Rafajłowej - Przełęcz Pantyrską - Jabłonica - Worochta. Ogółem w zawodach wzięło udział 1883 zawodników i zawodniczek, co daje średnią 313 osób w każdej edycji zawodów. Imprezę w latach 1934-1939 obejrzało około 8,5 tysiąca widzów, docierających na Huculszczyznę przeważnie pociągami popularnymi. Pewnie jeszcze więcej widzów oglądało zawody, nie opuszczając swego miejsca zamieszkania. Z myślą o jednych i drugich organizatorzy budowali podczas każdego marszu 2-3 trybuny drewniane, z których największa zawsze była w Worochcie, gdzie tradycyjnie kończył się trzeci etap. Tu też dość hojnie rozdawano nagrody. Najważniejszą z nich była nagroda przechodnia Marszałka Piłsudskiego, za zwycięstwo w grupie „mundurowej” (po jego śmierci nagroda stała się „wieczyście przechodnią"). Ogółem nagród przechodnich w 1934 roku było 5, w roku 1936 - 13, a w roku 1938 - już 18 . Wręczano też nagrody indywidualne. W roku 1936 rozdano aż 135 tego typu nagród. Największą popularnością cieszyły się pary nart, papierośnice, zegarki i budziki (11). Uczestnicy zawodów otrzymywali też odznaki pamiątkowe i okolicznościowe plakietki (25, s. 65-68). 


\section{Muzeum Huculskie w Żabiem i Oficerski Dom Wypoczynkowy}

Niemal od zawsze wiadomo, że jedną z najważniejszych instytucji, którą powszechnie odwiedzają turyści jest muzeum. Im bardziej bogate są jego zbiory, tym większe mają oni szanse na bliższe poznanie kraju czy regionu. Nie bez znaczenia są też forma artystyczna i rozmiary budynku muzealnego. Generalnie prawie zawsze monumentalność obiektu „zaświadcza” o „potędze” regionu. Tymczasem Huculszczyzna jeszcze w latach trzydziestych XX wieku, mimo międzynarodowej sławy kulturowej nie posiadała własnej placówki muzealnej. Co prawda istniały już w tym czasie maleńkie muzea w Truskawcu i Samborze, ale posiadały one przede wszystkim zbiory ogólnopolskiej sztuki ludowej. Nic też dziwnego, że na początku 1934 roku przy Zarządzie Głównym TPH powołano do życia Koło Naukowe, którego głównym zadaniem było podjecie trudu zbudowania okazałego ośrodka muzealno - naukowego. Po krótkich negocjacjach ustalono, że takie muzeum powinno być zbudowane w Żabiem, w miejscu - gdzie krzyżowały się liczne drogi Huculszczyzny, między innymi biegnące z Burkutu, Kosowa i Worochty. Placówka miała być „dopełnieniem terenu turystycznego, pokazującym najważniejsze wartości Huculszczyzny, nie tylko dla mieszkańców Polski, ale także cudzoziemców" (9). Zbudowane muzeum miało też wykazać związki kulturowe Huculszczyzny z Rzeczpospolita Polską. Reasumując - to miało być centrum promocji regionu, z uwzględnieniem celów pracy „państwowo - twórczej”.

Wiosną 1934 roku ukonstytuował się Komitet Wykonawczy Budowy Muzeum w Żabiu. Jego przewodniczącym został gen. T. Kasprzycki, a wiceprzewodniczącym Zygmunt Jagodziński, wojewoda stanisławowski. Podstawowym zadaniem Komitetu było zbieranie środków finansowych na budowę i wyposażenie placówki. Powołano też Komitet Honorowy Budowy, z udziałem wicepremiera i kilku ministrów. W kwietniu 1934 roku za kwotę 90.0oo zł została zakupiona w Żabiu spora parcela, na której miało być zbudowane muzeum. Miesiąc później wstępny projekt i kosztorys budowy przedstawił Zdzisław Mączewski, znany architekt warszawski. W CAW przechowywany jest projekt Muzeum Huculskiego, sygnowany datą 31 maj 1935 roku, opracowany w Biurze Planu Regionalnego Huculszczyzny przez inż. Edwarda Templina (3).

Jednak do ostatecznej realizacji wybrano projekt Stefana Listowskiego, profesora Politechniki Warszawskiej. Argumentem decydującym okazały się wysiłki autora projektu, zmierzające do nadania obiektowi „stylu huculskiego” (7). Głównym elementem tego stylu miał być kamień polny "dokładnie dobrany co do kształtu i koloru z okolic Żabiego", użyty do oblicowania głównej, trójdzielnej fasady budynku. Jego środkową część wypełniać miał kamień o barwie czerwonej, a flanki - jasnoszary. Całość miała imitować biało - czerwonego orła, siedzącego w „polskim gnieździe” (5). Zaprojektowany jednopiętrowy, podpiwniczony, z wysokim poddaszem budynek miał być najbardziej okazałym obiektem na Huculszczyźnie. Na parterze zaplanowano umieszczenie obszernej sali wystawowo odczytowej, kilka sal muzealnych, recepcję, archiwum, dwupokojowe mieszkanie (z kuchnią) dla dyrektora, hol wystawowy i pracownię fotograficzną. Na pierwszym piętrze znajdować się miały dwie sale muzealne, dziesięć pokoi gościnnych, kuchnia i węzły sanitarne. Podobne pokoje mieścić się miały na poddaszu. Po kolejnych negocjacjach - jedną z większych sal na parterze postanowiono przeznaczyć na schronisko turystyczne. Obiekt miał posiadać kanalizację wodno - sanitarną, centralne ogrzewanie i energię elektryczną otrzymywaną z agregatu. Był więc przystosowany do całorocznego wykorzystywania. Mogło w nim zamieszkać około 40 -tu osób w pokojach gościnnych i 20 osób w schronisku (5). Charakterystycznym elementem budynku było zwieńczenie wieży astronomiczno-meteorologicznej o wysokości około $13 \mathrm{~m}$, która również miała być elementem projektowanej budowy. Budżet przyjętego do realizacji 
budynku, o kubaturze około 14 ooo $\mathrm{m}^{3}$ i $1650 \mathrm{~m}^{2}$ powierzchni użytkowej zamykał się w kwocie 420.00o zł. Później kosztorys został zwiększony do 525.00o zł. TPH nie dysponowało taką kwotą (3). Ale pierwsze prace budowlane ruszyły pod koniec 1935 roku. Zakładano, że obiekt muzealny zostanie otwarty trzy lata później. W 1936 roku wzniesiono zasadniczą, kamienną część gmachu w stanie surowym. Wiosną 1937 roku gotowe było już skrzydło wschodnie i południowe, $\mathrm{z}$ dachem i wieżą astronomiczno-meteorologiczną. Zaczęto też montować urządzenia wodno-kanalizacyjne, centralnego ogrzewanie oraz instalację elektryczną. W pewnym momencie okazało się, że koszty wykonywanych robót znacznie przekraczają stan finansów „inwestorów”. Na niewiele pomogła pomoc wojewody stanisławowskiego, który na cel budowy muzeum przeznaczył 40.00o zł i Dyrekcji Lasów Państwowych nieodpłatnie przekazującej budowniczym drewno. W takich okolicznościach doszło do wstrzymania realizowanej inwestycji.

W tym miejscu należy odnotować, że budowa Muzeum Huculskiego zbiegła się w czasie z wysiłkami działającej w armii od 1928 roku Fundacji Oficerskich Domów Wypoczynkowych (FODW), która planowała w Żabiu wznieść swój „pomnikowy" ośrodek wypoczynkowy. Dokładnie 6 sierpnia 1935 roku fundacja kupiła tu cztery parcele ziemi o łącznej powierzchni prawie 14 ha. Szybko jednak okazało się, że nieuczciwy sprzedawca sprzedał wojsku działkę swoich sąsiadów (6). Sprawa trafiła do sądu i ciągnęła się kilkanaście miesięcy. W tym czasie starano się znaleźć jakieś rozwiązanie doraźne. Szansą było zawarcie stosownego porozumienia z TPH, które nie miało środków na dokończenie budowy i wyposażenie Muzeum Huculskiego. Obustronne konsultacje zakończyły się sukcesem. Wojsko zgodziło się udzielić budowniczym stosownej pomocy (100.00o zł), w zamian - na preferencyjnych warunkach, do momentu zbudowania własnego ośrodka - miało wynajmować część muzeum na potrzeby Oficerskiego Domu
Wypoczynkowego (ODW) (24, s. 3). W takiej sytuacji prace budowlane przy wznoszeniu muzeum w połowie 1937 roku zostały wznowione. Trwały one do stycznia 1938 roku (24, s. 3). Jesienią 1937 roku fundacja spisała z TPH stosowną umowę, na mocy której 1 maja 1938 roku mieli tu pojawić się pierwsi goście wojskowi (4). W dokumencie znalazł się też zapis, że TPH wynajmie fundacji pomieszczenia Muzeum Huculszczyzny z przeznaczeniem na ODW na okres trzech i pół roku. Za ten okres fundacja miała zapłacić stowarzyszeniu kwotę 25 tysięcy zł (15). Nieco wcześniej fundacja przekazała 26.800 zł, przeznaczoną na urządzenie ODW w wydzielonej części Muzeum (15). W takich okolicznościach dzięki zaangażowaniu wielu środowisk i pomocy wojska budowany obiekt został uroczyście otwarty 18 lutego 1938 roku. Pełnił on jednocześnie funkcje muzealne i wypoczynkowe.

Jednym z gości ODW w Żabiu była córka znanego płk. Stefana Grota-Roweckiego. Po latach, w swoich wspomnieniach, opisała wycieczkę do pobliskiej Worochty. W tekście znalazło się wiele słów podziwu dla ludu huculskiego i otaczającej go przyrody (Rowecka 1985: 161).

\section{Inne ważne inwestycje turystyczne}

Ważną atrakcją turystyczną Huculszczyzny było też Obserwatorium Meteorologiczno Astronomiczne im. Marszałka Jozefa Piłsudskiego, wzniesione na szczycie Popa Iwana, trzeciej co do wysokości góry czarnohorskiego pasma, przez którą przebiegała granica polsko-czechosłowacka. Kamień węgielny pod budowę obserwatorium położono latem 1936, a budynek uroczyście otwarto 29 lipca 1938 roku. Inwestycja kosztowała prawie milion zł. Ze względu na swój kształt budynek szybko zyskał przydomek „Biały Słoń”. W momencie oddawania do użytku obiekt uznawany był za najnowocześniejsze obserwatorium w Europie. Składał się on z 43 pomieszczeń i miał służyć przede wszystkim Państwowemu Instytutowi Meteorologicznemu w Warszawie do prowadzenie obserwacji meteorologicznych, głównie dla celów 
lotnictwa. W budynku stacjonowało też kilkunastu żołnierzy Korpusu Ochrony Pogranicza (35, s. 36).

Warto też odnotować zbudowanie w latach 1921-1922 z inicjatywy Sekcji Narciarskiej Polskiego Towarzystwa Tatrzańskiego w Stanisławowie skoczni narciarskiej w Worochcie. Była to skocznia sześćdziesięciometrowa, usytuowana na stokach Rebrowacza (1292 m n.p.m.), ponad przebiegającą niżej linią kolejową. W 1922 roku na obiekcie odbyły się trzecie Mistrzostwa Polski w skokach narciarskich. Do roku 1939 zorganizowano tu kilkanaście ogólnopolskich i regionalnych imprez narciarskich, które animowały turystykę sportową w szerokim tego słowa znaczeniu.

Ważnym elementem zagospodarowania Huculszczyzny było też wznoszenie na tym terenie sanatoriów, domów zdrowia i domów wypoczynkowych przez różne środowiska zawodowe II RP. Szczególnie mocno proces ten był widoczny w latach trzydziestych XX wieku, kiedy zbudowano tu kilkanaście tego typu obiektów. Można nawet powiedzieć, że budowy w trybie dobrowolnych opodatkowań domów zdrowotno-wypoczynkowych na Huculszczyźnie postrzegano wówczas w kategoriach ogólnopolskiego patriotyzmu. To miał być świadomy wkład polskich środowisk zawodowych w proces ożywiania gospodarczego tego biednego regionu. Warto w tym miejscu wymienić sanatorium Kasy Chorych, dom wypoczynkowy Stowarzyszenia Urzędników Skarbowych i dom zdrowia Akademików Żydowskich w Worochcie, sanatorium akademików lwowskich w Mikuliczynie, policyjny dom zdrowia i dom wypoczynkowy kolejarzy w Tatarowie, dom wypoczynkowy Stowarzyszenia Urzędników Skarbowych w Jamnej, dom zdrowia Związku Zawodowego Kolejarzy i dom wypoczynkowy nauczycieli szkół powszechnych w Jaremczu, domy wypoczynkowe stowarzyszenia „Rodzina Wojskowa” i Stowarzyszenia Urzędników Państwowych w Kosowie czy dom wypoczynkowy Warszawskiego Towarzystwa Narciarskiego w Rafajłowej.
Ważną rolę w procesie intensyfikacji działalności turystycznej odegrało Towarzystwo Tatrzańskie. Na terenie górskim Huculszczyzny działały cztery jego oddziały. Pierwszy został uruchomiony w Kołomyi, drugi we Lwowie, trzeci w Stanisławowie i czwarty, założony w 1935 roku, w Kosowie. W latach 1927-1939 Oddziały Towarzystwa Tatrzańskiego tylko w paśmie Czarnohory zbudowały następujące schroniska górskie: na Zaroślaku pod Howerlą (1927, było ono drugim - po schronisku nad Morskim Okiem w Tatrach), na połoninie Niżnej pod Doboszanką (1929), w Burkucie (1930), na Przełęczy Tatarskiej (1932), przy Klauzie Zubrynka pod Doboszanką (1937/38), na Skupowej (1938), pod Bałtagulem (1938), na Masnym Prysłupie (1938), na Prełucznym (1938), w dolinie Popadyńca (1938) i nowe w Burkucie (1939). Poza tym w latach 1938-1939 roku uruchomiono schroniska w: Rafajłowej, na Przełęczy Pantyrskiej, na Pasiecznym Wierchu, na połoninie Ruszczyna niedaleko szczytu Taupisz, w Worochcie, na połoninie Maryszewskiej, pod Kukulem, Popie Iwanie i w Kopilaszu (30). W roku 1935 na czarnohorskiej Kostrzycy swoje schronisko turystyczne w formie grażdy zbudował Związek Harcerstwa Polskiego, organizujący rokrocznie w okresie 1936-1938 na Huculszczyźnie około 8 o swoich obozów (1).

Swego rodzaju atrakcjami turystycznymi Huculszczyzny były wąskotorowe kolejki leśne, modernizowane i budowane głównie w latach trzydziestych. Można tu wymienić kolejkę z Worochty do Foroszczenki, czy też z Tatarówa do Mikuliczyna. W 1933 roku, dzięki staraniom głównie wybitnego botanika polskiego, Władysława Szafera, profesora Uniwersytetu Jagiellońskiego założono Czarnohorski Park Narodowy. Był on usytuowany na wschodniej stronie najwyższego szczytu Czarnohory - Howerli (2061 m) i obejmował obszar 1534 hektarów (23).

Warto też wspomnieć o przedsięwzięciach, które w sposób pośredni wpływały na promocję turystyczną Huculszczyzny i zwiększenie zainteresowania tym regionem różnych grup środowiskowych ówczesnej 
Polski. W pierwszej kolejności należy wymienić uruchomienie w roku 1933 roku bezpośredniego połączenia kolejowego Warszawy z Worochtą. W związku z tym, że podróż na Huculszczyznę trwała kilkanaście godzin, ostatnie wagony były przystosowane do organizacji ...dancingów. Nie bez znaczenia było też nazwanie w 1932 roku jedną z ulic stołecznego Mokotowa - Huculską. W 1937 roku stacjonujący w kołomyi 49 pułk strzelców 11 Dywizji Piechoty zyskał miano „huculskiego”, a jego żołnierze w mundurach galowych mieli elementy "huculskie” („korpusówki" w klapach munduru i kapelusz z pióropuszem).

\section{Zakończenie}

Z powyższych rozważań jasno wynika, że „odkrycie” Polskiej Huculszczyzny dla rodzimej turystyki miało miejsce na początku lat trzydziestych dwudziestego stulecia. To wtedy właśnie w polskich kręgach rządowych uruchomiono program działań, które w ciągu kilku lat uczyniły z tej ziemi drugi, po Zakopanem i Tatrach, region turystyczny kraju. Uruchomiony system promocji spowodował, ze główne ośrodki Huculszczyzny - takie jak Jaremcze, Worochta czy Żabie uzyskały status uzdrowisk. Powstało tu wówczas wiele nowych stylowych pensjonatów, domów letniskowych, sanatoriów, schronisk, lokali rozrywkowych, restauracji, kawiarni i kin. Tysiące polskiej młodzieży spędzało tu wakacje.

Tylko w Jaremczu w 1937 roku wypoczywało 10.000 wczasowiczów. Były tu dwa hotele, 44 pensjonaty i 56 willi $(21, \mathrm{~s} .3)$. W tym czasie Worochta stała się największym ośrodkiem sportów zimowych w Karpatach Wschodnich. Powstawały nowe drogi, szlaki turystyczne i obiekty, które aktywizowały zarówno miejscową ludność, jak i gości spoza Huculszczyzny. Przyjeżdżający turyści przyczyniali się do aktywizacji miejscowego życia gospodarczego, płacąc za zakwaterowanie, wyżywienie, bilety wstępu, czy kupując oferowane wyroby rzemieślniczo-artystyczne. Nie przypadkowo już w 1934 roku pojawiło się spostrzeżenie, że „każdy Hucuł, to artysta" (39, s. 22). W dłuższej perspektywie zakładano ściślejsze zespolenie ekonomiczne tej „wyspy etnograficznej” z resztą kraju (14). Turystyka była jedną z form realizacji tego celu. Naturalnie ówczesny rząd polski czynił bardzo wiele w innych obszarach życia społeczno- gospodarczego, aby ten romantyczny region mógł wyjść z „zapaści ekonomicznej”. Można więc z łatwością udowodnić, że lud huculski nigdy wcześniej, ani nigdy później nie uzyskał tak dużej sympatii i pomocy ze strony narodu, do którego należał.

Wiosną 1939 roku na łamach „Turyzmu Polski” ukazał się artykuł pt. „Zagospodarowanie turystyczne Karpat Polskich", z którego wynika, że infrastruktura turystyczna Huculszczyzny była w tym czasie gorsza tylko od Tatr i Zakopanego (41, s. 50-51). Działania promocyjno-turystyczne okazały się więc bardzo skuteczne. Szkoda, że ten romantyczny i ważny dla Polski region po zakończeniu II wojny światowej znalazł się w granicach Związki Radzieckiego. Dziś leży na terenie Ukrainy.

\section{Bibliografia}

Archiwum Akt Nowych, Zbiór Zespołów Szczątkowych, Akta Związku Harcerstwa Polskiego 19131939, sygn. 76, Sprawozdania ZHP z lat 1936-1938. Atrakcja Karpat Wschodnich. Święto Huculszczyzny, „Ilustrowany Kurier Codzienny”, 1934, nr 185, s. 22. Centralne Archiwum Wojskowe (CAW), Akta Departamentu Budownictwa (DB) Ministerstwa Spraw Wojskowych (MSWojsk.), sygn. I.300.63.233. CAW, Akta DB MSWojsk., sygn. I.30o.63.63, Notatka Centralnego Komitetu Wykonawczego (CKW) Fundacji ODW, z 15 stycznia 1937 roku.

CAW, Akta DB MSWojsk., sygn. I.30o.63.233, Opis techniczny Muzeum Huculskiego projektu Stefana Listowskiego.

CAW, Akta DB MSWojsk., sygn. I.30o.63.177, Pismo adwokata Zygmunta Goldstauba do Fundacji ODW, Z 15 września 1935 roku.

CAW, Akta DB MSWojsk., sygn. I.30o.63.233, Projekt Muzeum Huculskiego w Żabiu.

CAW, Akta DDO MSWojsk., sygn. 300.22.109, Okólnik wiceministra spraw wojskowych gen. T. Kasprzyckiego, z 28 grudnia 1933 roku 
CAW, Akta DDO MSWojsk., sygn. I.30o.22.109, Plan Pracy na Huculszczyźnie.

CAW, Akta DDO MSWojsk., sygn. I.300.22.109, Uwagi do projektu organizacji sezonu zimowego na Huculszczyźnie.

CAW, Akta Departamentu Dowodzenia Ogólnego (DDO) MSWojsk., sygn. I.30o.22.117., Wykaz nagród indywidualnych i zespołowych III Marszu Zimowego Huculskim Szlakiem II Brygady Legionów .

CAW, Akta Gabinetu MSWojsk., sygn. I.30o.1.644, Program Święta Huculszczyzny w powiecie kosowskim.

CAW, Akta Gabinetu MSWojsk., sygn. I.30o.1.644, Sprawozdanie kpt. Adama Kowalskiego ze „Święta Huculszczyzny", sporządzone 21 czerwca 1933 roku. CAW, Akta Oddziału II Sztabu Generalnego, sygn. I.303.4.122, Opracowanie pt. „Zagadnienia Ziem Wschodnich w świetle bezpośredniej obserwacji terenu".

CAW, Akta Szefa Sztabu Głównego (SSG) MSWojsk., sygn. I.303.1.13, Protokót 54 posiedzenia CKW Fundacji ODW $z$ dnia 29 listopada $1937 r$.

CAW, Akta SSG MSWojsk., sygn. I.303.1.13, Załącznik nr 4 do protokołu CKW Fundacji ODW z dnia 29 listopada 1937 roku. Wydatki na budowę ODW w okresie budzetowym 1937/1938.

CAW, Akta Wojskowego Biura Historycznego (WBH) MSWojsk., sygn. I.341.1.36, Projekt organizacji stacji naukowej i muzeum huculskiego.

Choroszy A.J., 1991, Huculszczyzna w literaturze polskiej, Wrocław, s. 17 i 153.

Faecher S., Narciarskie góry w Polsce, „Turysta w Polsce", 1934, nr 2, s. 4.

Hordt H., 1998, Piękno ziemi utraconej, Wrocław, s. 68.

Jaremcze, „Wiadomości Turystyczne”, 1938, nr 4, s. 3. Kolankowski J.,1989, Gdzie szum Prutu, Czeremoszu..., Wrocław, s. 102.

Kresy w życiu Polski i narodu polskiego, www.kworum.com.pl dostęp 10.10.2017.

Maciejewski K., J., Muzeum Huculskie i Szkota Rolnicza w Żabiu, „Polska Zbrojna”, 1938. nr 55, s. 3.

Maruszczak J., Na legionowym szlaku - odznaki pamiatkowe huculskiego marszu Szlakiem II Brygady Legionów (1934-1939), „Biuletyn Numizmatyczny”, 2009, nr 1, s. 65-68.

Minister gen. T. Kasprzycki otworzył obrady zjazdu Zwiąku Ziem Górskich, „Polska Zbrojna”, 1937, nr 231, s. 1.
Orłowicz M., 1932, Ankieta w sprawie Karpat Wschodnich. Protokót ankiety odbytej na zaproszenie Urzędu Wojewódzkiego w Stanisławowie, $z$ inicjatywy Ministerstwa Robót Publicznych, w dniach 29-30 maja1931 roku, Warszawa, s. 14-91.

Orłowicz M., 1935, Turystyka w Karpatach Polskich. Protokót i uchwaty III Zjazdu w odbytego w Wiśle w dniach 10-11 maja 1935 roku, Warszawa 1935, s. 3. O wierchowinie huculskiej, Jednodniówka wydana przez Towarzystwo Przyjaciół Huculszczyzny, z okazji „Święta Huculszczyzny”, Warszawa 1934, s. 13-14.

Polskie dzieje huculszczyzny, www.kworum.com.pl./ article dostęp 10.10.2017.

Przygotowania do „Święta Huculszczyzny”, „Polska Zbrojna", 1933, nr 147, s. 8.

Rowecka-Mielczarska I., 1985, Ojciec. Wspomnienia córki gen. Stefana Grota-Roweckiego, Warszawa, s. 161.

Skłodowski J., Rzeczpospolita Rafajtowska. Epizody wojenne i pomniki legionowe, „Almanach Karpacki", 2009, nr 38, s. 19-25.

Statut Towarzystwa Przyjaciół Huculszczyzny, Warszawa 1934, s. 4-6.

Śledziński J., Badania na szczycie, "Geodeta”, 1997, nr 5 , s. 36.

Święto Huculszczyzny i tegoroczny kalendarz imprez huculskich, „Wiadomości Turystyczne”, 1934, nr 8, s. 4.

Święto Huculszczyzny 15, 16, 17 i 18 czerwca 1933 roku. Wielka impreza turystyczna $w$ dolinie Prutu, Czeremoszu i Bystrzycy, Stanisławów 1933.

Święto Huculszczyzny, „Ilustrowany Kurier Codzienny", 1933, nr 154, s. 6.

Święto na Huculszczyźnie, „Ilustrowany Kurier Codzienny", 1934, nr 192, s. 22.

Tegoroczne święta turystyczne, „Wiadomości Turystyczne", 1935, nr 2, s. 2.

Tokarski Z., Zagospodarowanie turystyczne Karpat Polskich, „Turyzm Polski”, 1939, nr 3, s. 50-51.

Udziat wojska w Święcie Huculszczyzny, „Żołnierz Polski", 1933 nr 28, s. 486.

Wesele huculskie. Ciekawy obrzadek folklorystyczny, „Polska Zbrojna”, 1937, nr 231, s. 7.

W Karpatach Wschodnich, „Polska Zbrojna”, 1937, nr 302, s. 6.

Wspaniały przebieg Święta Huculszczyzny, „Ilustrowany Kurier Codzienny", 1934, nr 189, s. 3.

Zieleniewski T., 1934, Szczytami Karpat, Warszawa, s. 3 . 


\title{
Tourism as the main form of social and economic development of the Hutsul region in the period of Second Republic of Poland
}

\begin{abstract}
One of the more fascinating cultural and climatic regions of the II Republic of Poland was Hutsul region located in Stanisławów Voivodeship. Initially, the region was outside the circle of interests of tour operators. Only just the early thirties of the twentieth century was considered that Hutsul region should become an important element of Polish tourism and sport policy. First and foremost the contemporary Ministry of Military Affairs was designated to accomplish this task. An important role also come, on established in 1932, Friends of Hutsul Region Association. In the years 1933-1935 - in the summer time - nationwide "Hutsul Festivals" were organized. Its "winter" counterpart was the Winter Marches of Hutsul's Rout of the II Brigade of Polish Legions. Tourist-sport events, largely of political and propaganda character, were accompanied by a fight to improve the tourist infrastructure. The main aspect of this was uprising in 1935-1938 the magnificent - even monumental - Hutsul Museum in Żabie. As a result - at the end of the interwar period - Hutsul region became a region competing with Tatra Mountains and Zakopane for the primacy in tourist aspect.
\end{abstract}

\section{Keywords}

Hutsul region, tourism, sport, recreation, winter marches, the Polish Legions, museum, Friends of Hutsul Region Association 